\title{
PERIODONTAL PROFILE AND PRESENCE OF PERIODONTAL PATHOGENS IN YOUNG AFRICAN-AMERICANS FROM SALVADOR, BA, BRAZIL
}

\author{
Ligia Valéria Victor; Sheila Cavalca Cortelli; Davi Romeiro Aquino; Jonas de Carvalho Filho; \\ José Roberto Cortelli* \\ Universidade de Taubaté, Taubaté, SP, Brasil
}

Submitted: May 24, 2007; Returned to authors for corrections: September 22, 2007; Approved: February 18, 2008.

\begin{abstract}
This cross-sectional study evaluated the periodontal status and the presence of periodontopathogens in 132 young, black ethnic subjects who live in Salvador/Bahia-Brazil and have never smoked. Periodontal Probing Depth (PPD), Clinical Attachment Level (CAL), Plaque Index (PI) and Gingival Index (GI) were measured and analyzed by ANOVA and Wilcoxon tests $(\mathrm{p}<0.05)$ according to gender and age. The presence of A.actinomycetemcomitans, P.gingivalis, E.corrodens and F.nucleatum was determined by PCR and was analyzed by ANOVA, Wilcoxon, Student-t tests $(\mathrm{p}<0.05)$. Mean values of PPD and CAL were 2.18 and $1.0 \mathrm{~mm}$, respectively. Clinical parameters did not show differences between subjects of varying gender and age. The microbial prevalence was observed to be $95.45 \%$ for E.corrodens followed by F.nucleatum with $68.18 \%$, A.actinomycetemcomitans with $45.45 \%$ and P.gingivalis with $40.9 \%$. An association between the presence of pathogens and gender and age was not observed $(\mathrm{p}<0.05)$. PPD, CAL and PI were not associated with P.gingivalis; however, GI appeared in higher frequencies among subjects without P.gingivalis. In this young, black ethnic, Brazilian population, a high percentage (96.96\%) of subjects harbored at least one selected periodontal pathogen, but most subjects showed a healthy periodontal status. Further investigations are required to evaluate the actual influence of the presence of these bacterial species.
\end{abstract}

Key-words: African-Americans; Bacteria; Epidemiologic studies; Teen health; Periodontics.

\section{INTRODUCTION}

Periodontal disease is a pathology that is closely related to the presence of biofilm. However, its course is also related to other factors such as the quality of host response and other risk factors. Cross-sectional studies are performed in order to allow for the direct observation of a number of subjects in a single time frame. In this specific kind of study, the target population can be defined by demographic, geographic, political or administrative criteria (13) such as age, ethnic group or dwelling.

Epidemiological surveys are often designed to point out the conditions of health and disease in several populations. In Brazil, the epidemiological survey of 1986 (27) demonstrated a high prevalence of periodontal disease. Subsequent data from SB-
Brasil-2003 (28) showed an improvement in the periodontal condition; however, the actual data was masked by the high number of subjects over the age of 50 who were missing teeth.

Few descriptive and rare analytic studies have been made among the Brazilian population (32). Nevertheless, the available comparative analyses, which could provide clear understanding of studies countrywide, cannot be applied, primarily because of lack of a standard criteria to define periodontal disease. Moreover, when evaluating a specific population segment or a convenience sample, the availability and the comparability become even more restricted.

Cross-sectional studies show variations in the Brazilian prevalent data regarding gingivitis and periodontitis $(2,25,40)$. Additionally, these studies also show variations that are related to the presence of periodontal pathogens in populations from

*Corresponding Author. Mailing address: Rua Professor Nelson Freire Campelo, 343 - Jardim Eulália, Taubaté, SP - Brasil. Cep: 12010-700. Tel.: ++55

12 81113141. E-mail: jrcortelli@uol.com.br 
different countries $(7,14,22,47)$. Methodological factors may partially justify these discrepancies because bias of information, memory or selection might interfere with the data development. Consequently, extra care must be taken in order to avoid or reduce possible aleatory errors derived from variability in clinical measurements.

Furthermore, cross-sectional studies have found correlations between a higher prevalence of periodontal disease and specific risk factors such as gender, age, smoking habits, socioeconomic and ethnic factors. Borrell et al. (9) observed a worse periodontal condition in African-Americans compared with Caucasians. Similar observations had already been made $(8,31)$, although an association with other factors, mainly socioeconomic ones, had not been investigated. However, Segundo et al. (38), after having evaluated the prevalence and distribution of periodontal disease in Arturo's African descendant community (Minas Gerais, Brazil), did not confirm the hypothesis of higher prevalence of periodontal disease in black ethnic groups.

Some bacterial species have frequently been observed in subjects affected by periodontal disease; among these species we can highlight Aggregatibacter actinomycetecomitans (formerly Actinobacillus actinomycetemcomitans), Prevotella intermedia, Porphyromonas gingivalis, Tannerella forsythia (Bacteroides forsythus), Campylobacter rectus, Eikenella corrodens and Treponema denticola $(14,20)$.

Because of the lack of data from both regional and ethnic minorities, we aimed to characterize the periodontal profile as well as the presence of $P$. gingivalis, A. actinomnycetemcomitans, E. corrodens, $F$. nucleatum in a convenience sample composed of subjects from the young, adult, black, ethnic Brazilian population located in Salvador-Bahia, Brazil.

\section{MATERIALS AND METHODS}

Participants for this cross-sectional study were recruited from students (aged $15-25$ years) living in a district named Distrito Sanitário Docente Assistencial Barra/Rio Vermelho/ Pituba, Ondina in Salvador, Bahia, Brazil. Ethnicity/color of skin (Caucasian/White, African-descendants/black, pardo/Mestizo, Asiatic/yellow or Indigenous population) was determined according to self-reported data as proposed by IBGE (10).

Among eligible participants, 6 reported to be White, 20 reported to be Mulatto, and 137 reported to be black or Africandescendant (3). After exclusion of current smokers $(n=5)$ and for attempt our main inclusion criteria, i.e ethnicity/color of skin, our convenience sample was composed of 132 young subjects submitted to clinical and microbiological examinations. All subjects signed an informed consent which was previously approved (CEP 152/2004) by the Institutional Committee on Research Involving Human Subjects.

Exclusion from the study was based on the following criteria: subjects with $\leq 15$ teeth, a history of smoking, uncontrolled systemic diseases such as diabetes, or an immunocompromised system, subjects who required antibiotic prophylaxis, and female subjects who were pregnant or breast-feeding; in addition, subjects with orthodontic devices or without the teeth needed for subgingival sampling, subjects undergoing periodontal treatment 12 months before the beginning of the study, and subjects who had taken antibiotics within 6 months prior to the clinical and microbial examination were also excluded from the study.

One trained and calibrated examiner registered all clinical measurements and collected the microbial samples. The calibration protocol followed similar methods described previously (6). The data analysis was performed to determine the intra-examiner reliability using standard error of measurement (s.e.m) for the continuous variables such as PPD, CAL and Kappa-statistics (K) for the categorical variables. Our examiner was considered calibrated upon reaching a s.e.m value $\geq 0.8$ and $\mathrm{K}$ value between 0.8 and 0.95 .

Data and personal information related to the medical and dental history of the subjects were obtained by questionnaire. In addition, the study population was classified in seven economic classes named A1, A2, B1, B2, C, D and E (1). Moreover, measurements of Periodontal Pocket Depth - PPD (mm), Clinical Attachment Level-CAL (mm), Plaque index - PI (presence, absence) and Gingival index - GI (presence, absence) (4) were obtained using a manual periodontal probe (PCPUNC15BR, Hu-Friedy).

A pooled subgingival sample was collected from each subject from mesio-buccal aspect of first molars and incisors using sterile paper points (Fine, Johnson and Johnson, New Brunswick, NJ, USA) inserted to the depth of the sulci after the removal of supragingival plaque using sterile curettes. For subjects without those teeth, microbial samples were obtained from second molars and lateral incisors. Paper points were removed after 60 seconds and immediately placed in phosphate-buffered saline ( $\mathrm{pH}$ 7.4) (Promega, Madison, WI, USA). The bacterial cells were dispersed by vortexing at the maximal setting for 1 minute and were then maintained at $-20^{\circ} \mathrm{C}$ until laboratory processing. The presence of $A$. actinomycetemcomitans, $P$. gingivalis, $E$. corrodens and $F$. nucleatum was determined by a polymerase chain reaction.

In the laboratory of Molecular Biology Laboratory/ University of Taubaté, SP, the bacterial suspensions were thawed and centrifuged at $12.000 \mathrm{xg}$ for $3 \mathrm{~min}$; DNA was then extracted from the pellet (Instagene purification matrix, BioRad Laboratories, Hercules, CA, USA). After centrifugation to remove cell debris, the supernatant was used for polymerase chain reaction (PCR) analysis. Briefly, $5 \mu 1$ of the sample was added to $45 \mu \mathrm{l}$ of reaction mixture containing $5 \mu \mathrm{l}$ of 10 X PCR buffer (Promega, Madison, WI, USA), 1.25 unit of Taq DNA polymerase (Promega, Madison, WI, USA), and $0.2 \mathrm{mM}$ of each deoxyribonucleotides (Pharmacia LKB, Piscataway, NJ, 
USA). PCR amplification was performed using a thermalcycler (Perkin Elmer Cetus, Wellesley, MA, USA). The primer (5'-3') sequences were as follows A.actinomycetemcomitans (AAA CCC ATC TCT GAG TTC TTC TTC and ATG CCAACT TGA CGT TAAAT), $P$. gingivalis (AGGCAGCTTGCCATACTGCG and ACT GTT AGC AAC TAC CGA TGT), E. corrodens (CTA ATA CCG CAT ACG TCC TAA G and CTA CTA AGC AAT CAA GTT GCC C), $F$. nucleatum (CAAATG CTT GTG TCA ATAATA CT and TTT AGAAAT GGT AGAATAAT), and the details of the PCR procedure were previously described (14). PCR products were analyzed using $1.5 \%$ agarose gel (Sigma, Dorset, UK) electrophoresis performed at $4 \mathrm{~V} / \mathrm{cm}$ in tris-acetate EDTA buffer (Promega, Madison, WI, USA). The gel was stained with $0.5 \mu \mathrm{g} / \mathrm{ml}$ ethidium bromide (Amershan, Airlington Heights, USA) and photographed under $300 \mathrm{~nm}$ ultraviolet light.

\section{Statistical analysis}

Clinical and microbial data were analyzed with the Software BioEstat 2.0 for Windows $(\mathrm{p}<0.05)$. Mean values/subject of PPD and CAL were statistically analyzed by ANOVA while mean frequencies/subject of PI and GI were analyzed using a Wilcoxon test.

The presence of $A$. actinomycetemcomitans, $P$. gingivalis, E. corrodens and $F$. nucleatum was also evaluated by Wilcoxon test. Furthermore, differences in clinical parameters between groups (with or without a given periodontal pathogen) were determined by ANOVA and Student t-tests.

\section{RESULTS}

One hundred and thirty-two young $(18.17 \pm 2.28$ years of age), black ethnic subjects were examined. This group included 60 males (18.48 \pm 2.40 years of age) and 72 females (17.91 \pm $2.15) ; 89 \%$ were from economic class $\mathrm{C}$, and $11 \%$ were from economic class D.

A total of 3318 teeth (a mean value of 25.14 teeth per participant) were clinically examined while 792 teeth were sampled (six teeth per participant) for microbial analysis. Periodontal pocket depth, clinical attachment level, plaque and gingival indices values according to gender are showed on Table 1. Significant differences in clinical parameters between subjects of different ages or gender were not observed.

The amplicate of PCR reactions on agarose gels demonstrated a higher $(\mathrm{p}<0.05)$ prevalence of $E$. corrodens, followed by $F$. nucleatum and finally followed by $A$. actinomycetemcomitans and P. gingivalis (Fig. 1). Only one subject did not harbor $E$. corrodens; due to its high prevalence, no statistical analysis was done with that pathogen. The presence of $P$. gingivalis, $A$. actinomycetemcomitans and $F$. nucleatum did not appear to be significantly associated $(\mathrm{p}<0.05)$ with gender and age (Fig. 2).

Periodontal Pocket Depth, Clinical Attachment Level and Plaque Index were not related with $P$. gingivalis. However, subjects
Table 1. Mean values of Periodontal Pocket Depth (PPD), Clinical Attachment level (CAL), Plaque Index (PI) and Gingival Index (GI) according to gender.

\begin{tabular}{ccccc}
\hline & $\begin{array}{c}\text { PPD } \\
\text { (range) }\end{array}$ & $\begin{array}{c}\text { CAL } \\
\text { (range) }\end{array}$ & $\begin{array}{c}\text { PI } \\
\text { (range) }\end{array}$ & $\begin{array}{c}\text { GI } \\
\text { (range) }\end{array}$ \\
& Mean \pm SD & Mean \pm SD & Mean \pm SD & Mean \pm SD \\
\hline Male & $(1-3 \mathrm{~mm})$ & $(1-2 \mathrm{~mm})$ & $(0-1)$ & $(0-1)$ \\
& $2.16 \pm 0.32$ & $1.05 \pm 0.27$ & $0.73 \pm 0.15$ & $0.08 \pm 0.16$ \\
Female & $2.19 \pm 0.37$ & $1.05 \pm 0.15$ & $0.69 \pm 0.18$ & $0.08 \pm 0.16$ \\
\hline TOTAL & $2.18 \pm 0.34$ & $1.05 \pm 0.21$ & $0.71 \pm 0.16$ & $0.08 \pm 0.16$ \\
\hline
\end{tabular}

$\mathrm{SD}$ - Standard Deviation.

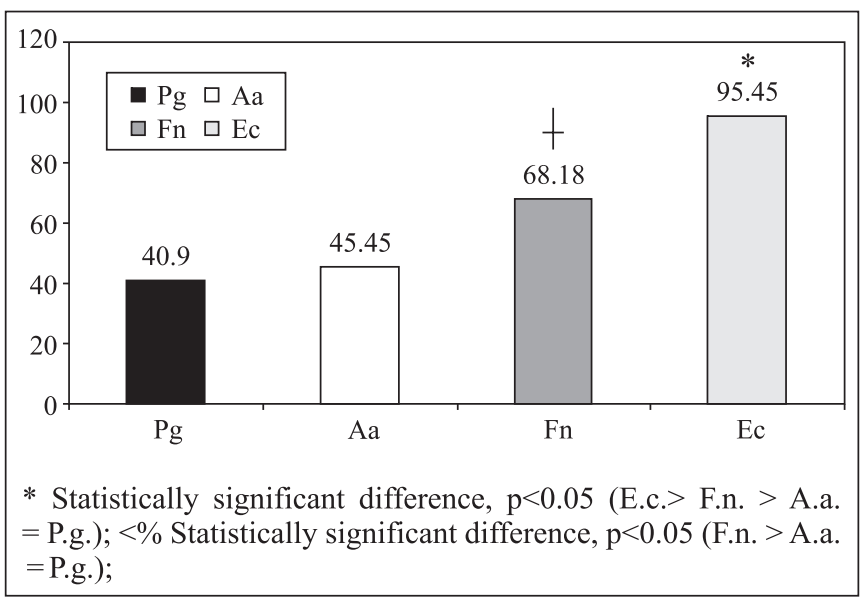

Figure 1. Prevalence (\%) of P. gingivalis (P.g.), A. actinomycetemcomitans (A.a.), F. nucleatum (F.n.) and $E$. corrodens (E.c.) in 132 young African-Americans subjects

who did not harbor $P$. gingivalis showed highest values of Gingival Index. The presence of both A. actinomycetemcomitans and $F$. nucleatum was not associated with any clinical measurements (Fig. 3).

\section{DISCUSSION}

In Brazil, epidemiological studies that can establish healthdisease criteria related to specific problems such as the periodontal profile are relatively scarce. Furthermore, when the goal of observation involves racial aspects, we encounter ethic, socio and political aspects that in many cases raise difficulties for the characterization of the population sample. In this context, in 2000, the Brazilian Institute of Geography and Statistic (10) characterized the Brazilian population in terms of color/race by using a self-classifying system, in which the interviewed person 


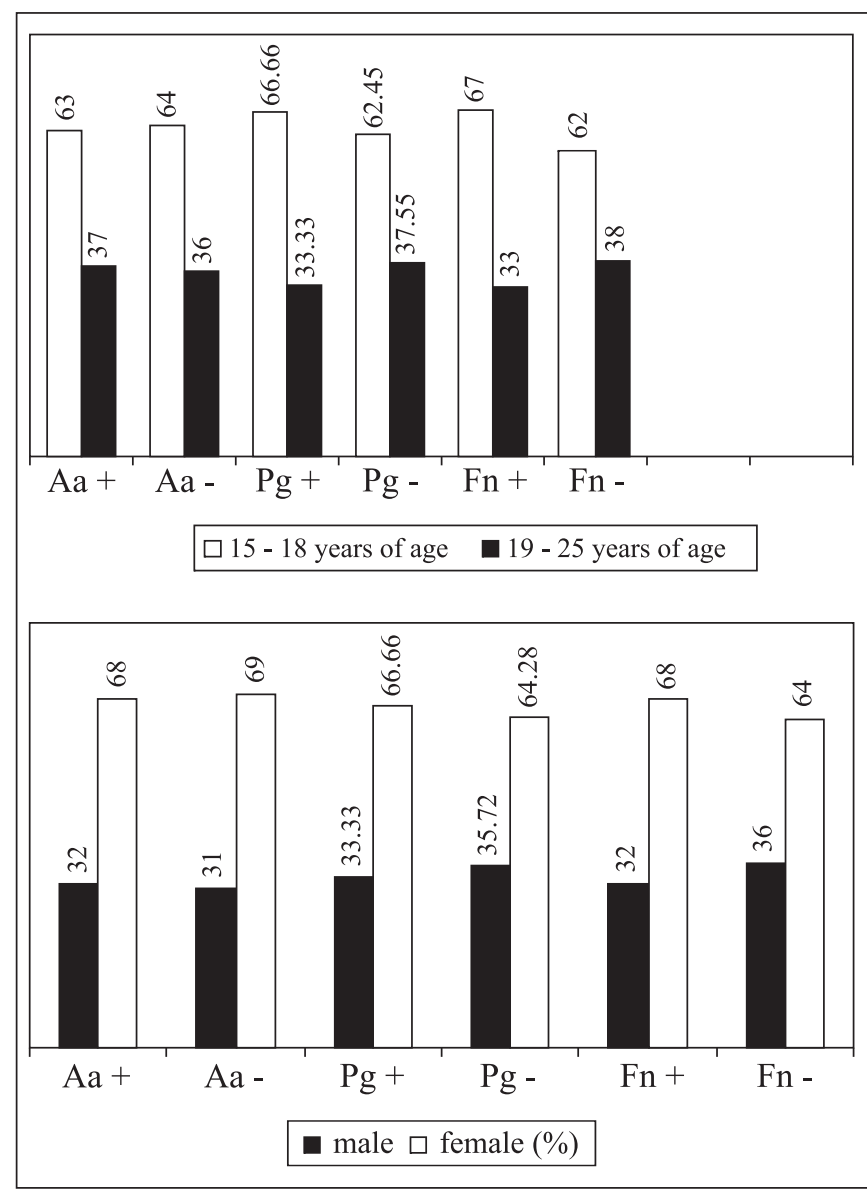

Figure 2. Percentage of positive (+) and negative (-) subjects for Aa (A. actinomycetemcomitans), $\mathrm{Pg}$ ( $P$. gingivalis) and $\mathrm{Fn}$ (F. nucleatum) according to gender and age.

could select the option which best fit him/her among the following classifications: White/Caucasian, Black/Africandescendants, Pardo/Mestizo, Yellow/Asiatic, Indigenous population or neither one (3).

As in most cross-sectional studies, we have adopted the convenience sampling criterion, in which the inherent selection bias is not designed to draw general conclusions. On the contrary, the proposal was to describe some clinical and microbiological aspects of a young, adult, black, ethnic group from Salvador - Bahia, a city that presents one of the highest population densities of African descendants in Brazil.

According to the parameters of periodontal probing depth, clinical attachment level and gingival bleeding, the results showed that periodontal disease was not prevalent. In this population, the mean value of the periodontal probing depth was $2.18 \mathrm{~mm}$, which is lower than the $3 \mathrm{~mm}$ usually required to characterize the disease $(5,34)$. On the other hand, the clinical attachment level parameter showed that the reduced mean value

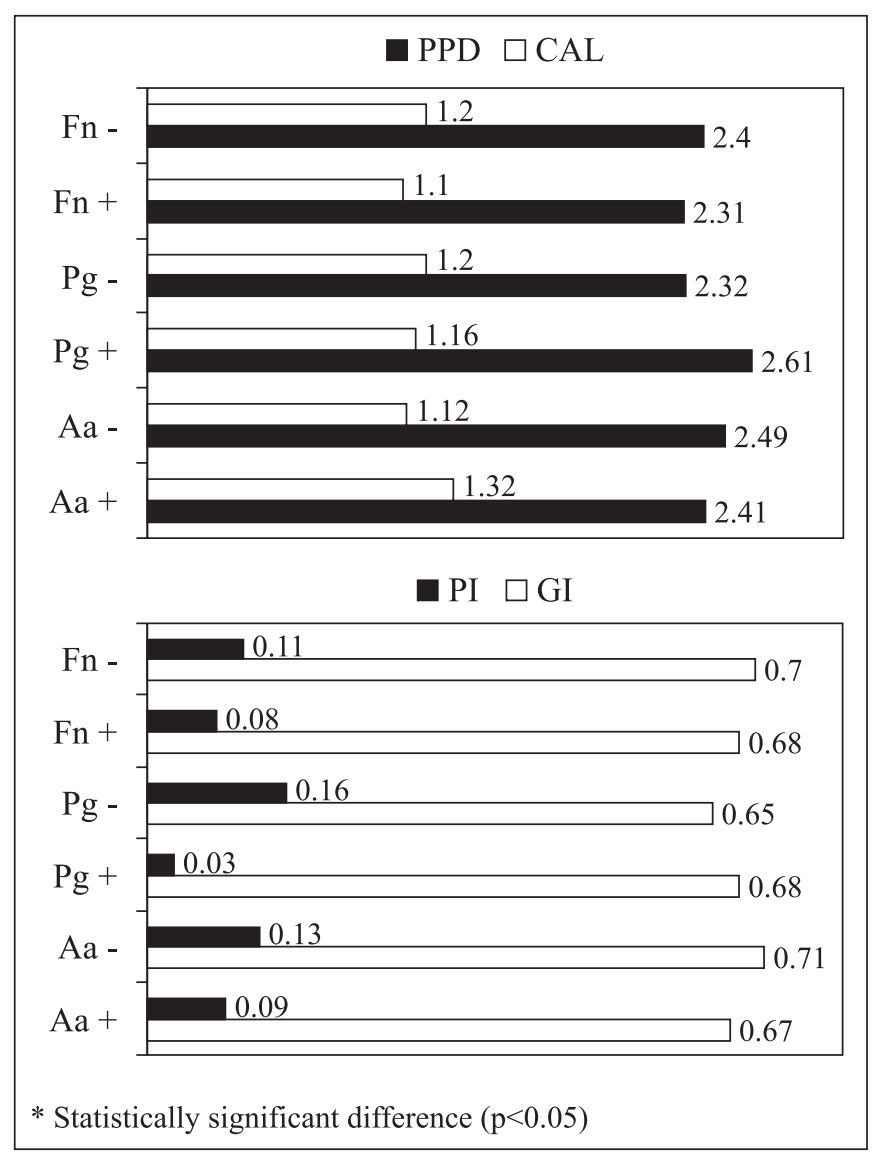

Figure 3. Mean values of PPD (periodontal pocket depth), CAL (clinical attachment level), Plaque Index (PI) and Gingival Index (GI) according to presence (+) or absence (-) of Aa ( $A$. actinomycetemcomitans), Pg ( $P$. gingivalis) and Fn (F.nucleatum).

(approximately $1.0 \mathrm{~mm}$ ) was similar to those observed in other periodontally healthy populations (45). Finally, our population did not fulfill the gingivitis criteria described by Lopez et al. (2002) (23), i.e., $>30 \%$ of bleeding periodontal sites, and only three participants fulfilled the Tanner's (42) definition of early periodontitis 1, i.e, mean clinical attachment level $<1.5 \mathrm{~mm}$ and least 1 site with $2 \mathrm{~mm}$ of attachment loss.

Another aspect to be considered is the results that were obtained for the gingival bleeding index. Our study showed mean values of 0.08 offering evidence of a condition also compatible with periodontal health, once the increase in number of bleeding sites increase the probability of periodontal disease (35). Only the plaque index was relatively high (0.71) and was similar to those observed among the population with periodontal disease (19). The results observed here differ from those observed by authors who reported higher occurrences of periodontal disease in African-descendant subjects compared 
to populations of different ethnic groups including Caucasians and Asians among others $(8,9,26,31,46)$.

Different studies have associated the diagnosis of periodontal disease with the presence of some periodontal pathogens. This association is very clear when the model "diagnosis of aggressive localized/generalized periodontitis and the presence of $A$. actinomycetemcomitans" $(11,15)$ is adopted. However, the colonization of these microorganisms per se will neither guarantee an inflammatory reaction nor the destruction of periodontal tissue (33). Some of these studies suggest that certain microbial associations are necessary to induce this disease (43), but these studies also suggest that these microorganisms, both isolated or associated, can also be present in clinically healthy subjects.

When evaluating bacterial presence, either isolated or ingroup, we can affirm that different microorganisms demonstrated high prevalent data for a healthy population, mainly E. corrodens and $F$. nucleatum. However, in Brazil, the oral occurrence of selected periodontal pathogens is still unclear. A study conducted by Avila-Campos (2003) (7) also demonstrated a high prevalence of $A$. actinomycetemcomitan (70\%), P. gingivalis $(66 \%)$ and F. nucleatum ( $92 \%)$ in the healthy population made up of subjects between 18-51 years of age and 10\% of blacks. Nevertheless, considering that the disease is dependent of host characteristics, we cannot affirm that the bare presence of these microorganisms represents an additional risk factor to the outbreak of the disease in the future.

Slots et al. (1995) (39) demonstrated that PCR is a sensitive, reproducible, and easy-to-perform technique for the detection of $A$. actinomycetemcomitans, T. forsythus, C. rectus, E. corrodens, $P$. gingivalis, $P$. intermedia, and T. denticola in crude subgingival specimens. It has also been applied in many recent prevalence studies such as Sakai et al. (2007) (37), Tachibana et al. (2006) (41) and Lee et al. (2005) (21). In this case, the most important issue to consider is the presence of suspected periodontal pathogens with the clinical periodontal status. Longitudinal studies would have to be conducted for this hypothesis to be established and confirmed.

Therefore, as previously reported (36), our study suggested that in addition to the presence of microorganisms, the quality of the host response from the subject associated or unassociated with indicators and risk factors should be considered for development of periodontal breakdown (36).

In general, the detection of $A$. actinomycetemcomitans is higher in sites of subjects with periodontal disease $(22,29,30)$. However, this pathogen can be present in lower proportions in clinically healthy subjects or in subjects with gingivitis. Cortelli et al. (16) researched A. actinomycetemcomitans in clinically healthy young adults and were able to use a less sensitive culture technique to document a pathogen prevalence of $14 \%$. Besides higher bacterial counts in periodontal diseased sites, we found more virulent bacterial strains. In addition, isolates from healthy subjects also showed pathogenic activity (17).
Similarly, the presence of $40 \%$ of $P$. gingivalis can be considered high once this bacteria is associated with periodontal disease (44), mainly chronic periodontitis $(29,44)$. In this study, we also verified prevalent data of nearly 68 and $95 \%$ for the $F$. nucleatum and E. corrodens, respectively, which can be associated with early stages of periodontitis (24). Similarly, the prevalence of $E$. corrodens in clinically healthy subjects was observed by Moore et al. (29).

Finally, another factor that may be important is the possible influence of geographical regions on oral colonization by periodontal pathogens, a factor which was previously reported among young (12) and adult populations (18). At this time, that possible influence still requires further investigation.

Among this young, black, ethnic Brazilian population, a high percentage $(96.96 \%)$ of subjects harbored at least one selected periodontal pathogen, but most subjects showed a periodontal healthy status. Further investigations are required to evaluate the actual influence of the presence of these bacterial species. Prospective studies that include the analyses of other ethnic groups of young adults are suggested in order to characterize the predictive values of these microorganisms as risk indicators.

\section{RESUMO}

\section{Condição periodontal e presença de patógenos periodontais em uma população jovem de brasileiros afro-descendentes}

O objetivo do presente estudo foi avaliar a condição periodontal e presença de periodonto-patógenos em uma amostra de 132 jovens não fumantes, afro-descendentes, residentes em Salvador/Bahia-Brasil. Profundidade de Sondagem (PS), Nível Clínico de Inserção (NCI), Índice de Placa (IP) e Índice Gengival (IG) foram mensurados e analisados pelos testes ANOVA e Wilcoxon $(p<0,05)$ em função do gênero e idade dos indivíduos. A. actinomycetemcomitans, $P$. gingivalis, $E$. corrodens e F. nucleatum foram identificados por PCR e analisados por ANOVA, Wilcoxon e $t$ de Student $(\mathrm{p}<0,05)$. Foram observados valores médios de PS e NCI de 2,18 e $1,0 \mathrm{~mm}$ respectivamente. Os parâmetros clínicos avaliados não sofreram influência dos fatores gênero e idade $(\mathrm{p}<0,05)$. E. corrodens foi a bactéria mais prevalente $(95.45 \%)$, seguido de $F$. nucleatum (68.18\%), A. actinomycetemcomitans (45.45\%) e P. gingivalis (40.9\%). Não foi observada associação entre os patógenos periodontais pesquisados com o gênero e idade dos indivíduos $(\mathrm{p}<0,05)$. PS, NCI e IP não estiveram associados a presença de $P$. gingivalis, todavia para o parâmetro IG este mostrou alta freqüência entre os indivíduos que não alocaram $P$. gingivalis. Nessa população jovem de brasileiros afro-descendentes um percentual $(96,96 \%)$ elevado de indivíduos apresentou pelo menos um patógeno periodontal, mas mostraram-se clinicamente 
saudáveis. Outras investigações são necessaries para avaliar a real influencia da presença dessas espécies bacterianas.

Palavras-chaves: Afro-descendentes; Bactérias; Estudos Epidemiológicos; Saúde do Adolescente; Periodontia.

\section{REFERENCES}

1. Abep - Associação brasileira de empresas de pesquisa. Critério de classificação econômica Brasil. (2003). [Cited in 11/05/2007]. Available: URL: http://www.abep.com.br.

2. Abbeg, C. (1997). Oral hygiene habits among Brazilian adults in an urban area of Southern Brazil. Rev. Saúde Pub., 31: 586-593.

3. Adorno, R.C.F.; Alvarenga, A.T.; Vasconcelos, M.P. (2004). Quesito cor no sistema de informação em saúde. Estudos Avançados, 1815: 119-123.

4. Ainamo, J.; Bay, I. (1975). Problems and proposals for recording gingivitis and plaque. Int. Dent. J., 25: 229-235.

5. American Academy of Periodontology. (1999). International workshop for a classification of periodontal diseases and conditions. Ann. Periodontol., 4: 1-6.

6. Araujo, M.W.B.; Benedek, K.M.; Benedek, J.R.; Grossi, S.G.; Dorn, J.; Wactawski-Wende, J.; Genco, R.J.; Trevisan, M. (2003). Reproducibility of probing depth measurements using a constant force electronic probe: analysis of inter- and intra-examiner variability. J. Periodontol, 74: 1736-1740.

7. Ávila-Campos, M.J. (2003). PCR detection of four periodontapathogens from subgingival clinical samples. Braz. J. Microbiol., 34: 81-84.

8. Borrell, L.N.; Taylor, G.W.; Borgnakke, W.S.; Nyquist, L.V.; Woolfolk, M.W.; Allen, D.J.; Lang, W.P. (2003). Factors influencing the effect of race on established periodontitis prevalence. J. Public Health Dent., 63: 20-29.

9. Borrell, L.N.; Burt, B.A.; Gillespie, B.W.; Lynch, J.; Neighbors, H. (2002). Periodontitis in the United States: Beyond black and white. J. Public Health Dent., 62: 92-101.

10. Brasil. Instituto Brasileiro de Geografia e Estatística. População: censo 2000. [Cited in 01/11/2005]. Available: http://www.ibge.gov.br.

11. Cappelli, D.P.; Ebersole, J.L.; Korman, K.S. (1994). Early-onset periodontitis in Hispanic-American adolescents associated with $A$. actinomycetemcomitans. Community Dent. Oral Epidemiol., 22: 116-121.

12. Celenligil, H.; Ebersole, J.L. (1998). Analysis of serum antibody responses to periodontopathogens in early-onset periodontitis patients from different geographical locations. J. Clin. Periodontol., 25: 994-1002.

13. Cortelli, J.R.; Lotufo, R.F.M.; Oppermann, R.V.; Sallum, A.W. (2005). Glossário da Sociedade Brasileira de Periodontologia. 1th ed. São Paulo: SOBRAPE.

14. Cortelli, J.R.; Cortelli, S.C.; Jordan, S.F.; Haraszthy, V.I.; Zambon, J.J. (2005). Prevalence of periodontal pathogens in brazilians with aggressive or chronic periodontitis. J. Clin. Periodontol., 32: 860866.

15. Cortelli, S.C.; Jorge, A.O.C.; Cortelli, J.R.; Jordan, S.F.; Haraszthy, V.I. (2003). Detection of highly and minimally leukotoxic Actinobacillus actinomycetemcomitans strains in patients with periodontal diseases. Pesqui. Odontol. Bras., 17: 183-188.

16. Cortelli, S.C.; Feres, M.; Shibli, J.; Figueiredo, L.; Padilha de Oliveira, V.; Cortelli, J.R. (2005). Presence of Actinobacillus actinomycetemcomitans on the Community Periodontal Index (CPI) Teeth in Periodontally Healthy Individuals. J. Contemp. Dent. Pract., 6: 85-93.

17. Gaetti-Jardim, E.J.; Luvizotto, M.C.R.; Avila-Campos, M.J. (2000). Virulence of oral fusobacterium nucleatum from humans and nonhuman primates in mice. Braz. J. Microbiol., 31: 146-150.
18. Haffajee, A.D.; Bogren, A.; Hasturk, H.; Feres, M.; Lopez, N.J.; Socransky, S.S. (2004). Subgingival microbiota of chronic periodontitis subjects from different geographic locations. J. Clin. Periodontol., 31: 996-1002.

19. Kocher, T.; Schwahn, C.; Gesch, D.; Bernhardt, O.; John, U.; Meisel, P.; Baelum, V. (2005). Risk determinants of periodontal disease-an analysis of the Study of Health in Pomerania (SHIP 0). J. Clin. Periodontol., 32: 59-67.

20. Kumar, P.S.; Griffen, A.L.; Barton, J.A.; Paster, B.J.; Moeschberger, M.L. (2003). New bacterial species associated with chronic periodontitis. J. Dent. Res., 82: 338-344.

21. Lee, S.M.; Yoo, S.Y.; Kim, H.S.; Kim, K.W.; Yoon, Y.J.; Lim, S.H.; Shin, H.Y.; Kook, J.K. (2005). Prevalence of putative periodontopathogens in subgingival dental plaques from gingivitis lesions in Korean orthodontic patients. J. Microbiol., 43: 260-265.

22. Lopez, N.J.; Melhado, J.C.; Leighton, G.X. (1996). Occurrence of Actinobacillus actinomycetemcomitans, Porphyromonas gingivalis and Prevotella intermedia in juvenile periodontitis. J. Clin. Periodontol., 23: 101-105.

23. Lopez, N.J.; Smith, P.C.; Gutierrez, J. (2002). Periodontal therapy may reduce the risk of preterm low birth weight in women with periodontal disease: a randomized controlled trial. J. Periodontol., 73: 911-924.

24. Lopez, N.J. (2001). Epidemiology of clinical attachment loss in adolescents. J. Periodontol., 72: 1666-1674.

25. Machion, L.; Freitas, P.M.; Cesar Neto, J.B.; Nogueira Filho, G.R.; Nociti Jr., F.H. (2000). A influência do sexo e da idade na prevalência de bolsas periodontais. Pesq. Odont. Bras., 14: 33-37.

26. Melvin, W.L.; Sandifer, J.B.; Gray, J.L. (1991). The Prevalence and sex ratio of juvenile periodontitis in racially mixed population. $J$. Periodontol., 62: 330-334

27. Ministério da Saúde. (1986). Divisão Nacional de Saúde Bucal. Levantamento epidemiológico em saúde bucal: Brasil, zona urbana, 1986. Brasília (DF); Centro de Documentação do Ministério da Saúde.

28. Ministério da Saúde. (2004). Projeto SB Brasil 2003: condições de saúde bucal da população brasileira 2002 - 2003: resultados principais/ Ministério da Saúde, Secretaria de Atenção a saúde, Departamento de Atenção Básica - Brasília: Ministério da Saúde.

29. Moore, W.E.C.; Holdeman, L.V.; Cato, E.P.; Smibert, R.M.; Burmeister, J.A.; Palcanis, K.G. (1985). Comparative microbiology of juvenile periodontitis. Infect. Immun., 48: 507-19.

30. Müller, H.P.; Eickholz, P.; Heinecke, A.; Pohl, S.; Müller, R.F.; Lange, D.E. (1995). Simultaneous isolation of A. actinomycetemcomitans from subgingival and extracrevicular locations of the mouth. J. Clin. Periodontol., 22: 413-419.

31. Oliver, R.C.; Brown, J.L.; Löe, H. (1998). Periodontal diseases in the United States population. J. Periodontol., 69: 269-278.

32. Oppermann, R.V.; Susin, C.; Cortelli, S.C.; Rosing, C.K.; Araujo, M.W.B.; Costa, F.O.; Corraini, P. (2005). Epidemiologia das doenças periodontais. Periodontia, 15: 62-66.

33. Papapanou, P.N. (2006). Subgingival microbiota in adult Chinese: prevalence and relation to periodontal disease progression. $J$. Periodontol., 68: 651-666.

34. Pion. (2006). Condição periodontal de um subgrupo populacional do município de Guarulhos, SP. Rev. Bras. Epidemiol., 9: 335-345.

35. Rahardjo, A.; Yoshihara, A.; Amarasena, N.; Ogawa, H.; Nakashima, K.; Miyazaki, H. (2005). Relationship between bleeding on probing and periodontal disease progression in community-dwelling older adults. J. Clin. Periodontol., 32: 1129-1133.

36. Raggahianti, M.S. (2004). Influence of age, sex, plaque and smoking on periodontal conditions in a population from Bauru, Brasil. $J$. App. Oral Sci., 12: 457-462.

37. Sakai, V.T.; Campos, M.R.; Machado, M.A.; Lauris, J.R.; Greene, A.S.; Santos, C.F. (2007). Prevalence of four putative periodontopathic bacteria in saliva of a group of Brazilian children 
with mixed dentition: 1-year longitudinal study. Int. J. Paediatr. Dent., 17: 192-199.

38. Segundo, T.K.; Ferreira, E.F.; Costa, J.E. (2004). A doença periodontal na comunidade negra dos Arturo's, Contagem, Minas Gerais, Brasil. Cad.Saúde Pública, 20: 596-603.

39. Slots, J.; Ashimoto, A.; Flynn, M.J.; Li, G.; Chen, C. (1995). Detection of putative periodontal pathogens in subgingival specimens by $16 \mathrm{~S}$ ribosomal DNA amplification with the polymerase chain reaction. Clin. Infect. Dis., 202: S304-S307.

40. Susin, C.; Albandar, J.M. (2005). Agressive periodontitis in an urban population in southern Brazil. J. Periodontol., 76: 468-475.

41. Tachibana, M.; Yoshida, A.; Ansai, T.; Takata, Y.; Akifusa, S.; Fukuhara, M.; Hamasaki, T.; Okuda, K.; Takehara, T. (2006). Prevalence of periodontopathic bacteria on the tongue dorsum of elderly people. Gerodontology, 23: 123-126.

42. Tanner, A.C.R.; Paster, B.J.; Lu, S.C.; Kanasi, E.; Kent, J.R.R.; Van Dyke, T.; Sonis, S.T. (2006). Subgingival and tongue microbiota during early periodontitis. J. Dent. Res., 85: 318-323.
43. Tanner, C.; Hamada, S.; Holt, S.C.; Mcghee, J.R. (1991). Microbial succession in the development of periodontal disease. In: Periodontal Disease: Pathogens and Host Immune Responses. Tokyo: Quintessence, 22: 13-25.

44. Timmerman, M.F. (2001). Untreated periodontal disease in Indonesian adolescents. Subgingival microbiota in relation to experienced progression of periodontitis. J. Clin. Periodontol., 28: 617-627.

45. Timmerman, M.F.; Van der Weijden, G.A.; Abbas, F.; Arief, E.M.; Armand, S.; Winkel, E.G.; Van Winkelhoff, A.J.; Van der Velden, U. (2000). Untreated periodontal disease in Indonesian adolescents. Longitudinal clinical data and prospective clinical and microbiological risk assessment. J. Clin. Periodontol., 27: 932-942.

46. Umeda, M.; Chen, C.; Bakker, I.; Contreras, A.; Marrison, J.L.; Slots, J. (1998). Risk indicators for harboring periodontal pathogens. J. Periodontol., 69: 1111-1118.

47. Ximenez-Fyvie, L.A.; Almaguer-Flores, A.; Jacobo-Soto, V.; LaraCordoba, M.; Sanchez-Vargas, L.O.; Alcantara-Maruri, E. (2006). Description of the subgingival microbiota of periodontally untreated Mexican subjects: chronic periodontitis and periodontal health. $J$. Periodontol., 77: 460-471. 